\title{
Transformasional kepentingan rakyat dalam perspektif pemberdayaan masyarakat bagi penanganan kemiskinan sosial melalui Government Social Responsibility (GSR)
}

\section{Public interest transformation from the perspective of civil empowerment to overcome social poverty through Government Social Responsibility (GSR)}

\author{
F.X. Sudjatmoko \& Nur Dewi Setyowati \\ Fakultas Ilmu Sosial dan Ilmu Politik Universitas Merdeka Madiun \\ Jalan Serayu Tromol Pos No.12, Pandean, Madiun, Kota Madiun, Jawa Timur \\ Telepon: (0351) 464427. E-mail: aldryan95@gmail.com
}

\begin{abstract}
Poverty is a national problem that still cannot be solved by government until present. One of its causing factor is the inability of related policy to solve essential problems faced by poor society. As the result, there are many social programs which are expected to provide solution to poverty problem. Government Social Responsibility is an approach model in order to build relation toward harmonization between government and society, through effort of knowing and understanding problem that is faced by society directly, so it can be a reference in determining government policy that make closer between government action with public interest. The long-term purpose of this research is to get scientific information, teaching material, and as the guidance for handling social poverty problem. Moreover, this research especially aims to find a new model or concept and/or develop a model for handling poverty. The objects of this study are official bureaucracy or government and society in East Java Province. Through Government Social Responsibility program, it is expected to minimize discrepancy between government interest with society interest, and it is expected that government policy is more oriented to aspiration and broad society interest, so that social programs can be a right solution in effort to overcome poverty.
\end{abstract}

Keywords: government social responsibility, society empowerment, social poverty handling

\begin{abstract}
Abstrak
Kemiskinan adalah persoalan nasional yang hingga saat ini masih belum dapat diselesaikan oleh pemerintah. Salah satu faktor penyebab kemiskinan adalah ketidak mampuan pemerintah untuk menyediakan kebijakan yang dapat menyelesaikan permasalahan yang dihadapi kelompok miskin. Berbagai program sosial diharapakan dapat menyediakan solusi untuk masalah kemiskinan. Government Social Responsibility adalah model pendekatan untuk membangun harmonisasi antara pemerintah dan masyarakat, melalui upaya untuk memahami masalah yang dihadapi oleh masyarakat sehingga dapat menjadi referensi untuk memutuskan kebijakan pemerintah. Tujuan jangka panjang penelitian ini adalah untuk mendapatkan informasi akademik, materi pengajaran, dan arahan untuk menyelesaikan permasalahan kemiskinan. Penelitian ini secara khusus bertujuan untuk menemukan model baru atau konsep kebijakan untuk mengatasi kemiskinan. Objek studi ini adalah pegawai birokrasi atau pemerintah di Jawa Timur. Melalui program GSR, diharapkan dapat meminimalisir perbedaan antara kepentingan pemerintah dan masyarakat, dengan harapan kebijakan pemerintah dapat lebih diorientasikan pada aspirasi dan kepentingan masyarakat luas, sehingga program sosial dapat menjadi solusi yang tepat untuk menyelesaikan persoalan kemiskinan.
\end{abstract}

Kata kunci: government social responsibility, pemberdayaan sosial, penanganan kemiskinan sosial

\section{Pendahuluan}

Government Social Responsibility dapat menjadi format pendekatan oleh pejabat publik kepada masyarakat luas, khususnya masyarakat yang mengalami kurang beruntung (miskin), dimana kajian Government Social Responsibility memiliki dua perspektif kajian. Pertama, Government Social Responsibility merupakan strategi atau pendekatan yang dikembangkan untuk menarik simpati masyarakat, dalam rangka meraih dukungan program-program pemerintah. Kedua, Government Social Responsibility sebagai strategi atau pendekatan untuk mengenal dan memahami secara 
kondisional masyarakat yang akan menjadi referensi bagi pemerintah dalam menentukan kebijakan. Dengan demikian, Government Social Responsibility memiliki makna yang strategis bagi kepentingan masyarakat luas, yaitu mendekatkan antara kepentingan masyarakat dengan kepentingan pemerintah sehingga orientasi kebijakan pemerintah benar-benar merupakan cerminan dari aspirasi dan kepentingan masyarakat luas.

Pendekatan yang berorientasi kepada program dan kebijakan memiliki kedekatan hubungan dengan pendekatan yang berorientasikan kepentingan masyarakat dan kepentingan pemerintah. Sebagai akibat dari padanya, adalah bahwa kedua pendekatan dan perspektif dimaksud adalah diperlukan adanya dukungan dari semua pihak yang terkait, melalui keterlibatan (peran-serta) warga masyarakat pada umumnya, terutama dari warga masyarakat yang menghadapi keadaan kurang beruntung (miskin). Hasil penelitian (Sudjatmoko \& Baru 2009) menyatakan bahwa; "program-program pembangunan juga perlu dikomunikasikan kepada warga masyarakat di wilayah di mana mereka tinggal menjadi sasaran atau lokasi penyelenggaraan pembangunan guna menstimulasi bagi keikutsertaan (partisipasi) secara aktif oleh warga masyarakat, tanpa kecuali”.

Melalui gambaran-gambaran kegiatan pemerintah daerah, seperti; kunjungan kerja yang lebih dikenal dengan sebutan silaturahim yang diselenggarakan oleh pemerintah Kota Madiun; juga di Kabupaten Madiun dengan kegiatan Bhakti Sosial Terpadu (BST); dan di Kabupaten Magetan dengan kegiatan pemerintah melalui saba desa, di dalam laporan hasil penelitian sebelumnya (tahun pertama) dapat diketahui proses dan prosedur yang menciptakan pola kegiatan di masing-masing wilayah. Keterangan tersebut, mengindikasi bahwa pemerintah tidak mungkin dapat menyelesaikan kegiatan pembangunan melalui kemampuan sendiri tanpa adanya keterlibatan (peran-serta) secara aktif dari warga masyarakat.

Sementara itu, pengembangan pola komunikasi pemerintah terhadap masyarakat dilakukan melalui komunikasi instruktif dan berjalan searah, sehingga masyarakat hanya menjadi obyek semata dalam pembangunan, sifatnya menerima dan melaksanakan program-program pemerintah. Komunikasi seperti itu, kurang tepat dijadikan landasan dalam pengambilan kebijakan pembangunan, sebab masyarakat tidak diberi atau tidak memiliki ruang bagi penyampaian aspirasi dan kepentingannya, sehingga bersifat apatis. Dari hasil temuan berdasarkan penelitian Tim FK3 Fisip-Unmer Madiun (Baru et al. 2008) juga menyebutkan bahwa; "Pelibatan masyarakat dalam penyusunan program pembangunan, hanya sekedar memenuhi standar normatif saja".

Ruang transparansi dan akuntabilitas dibuka selebar mungkin untuk mengurangi rasa curiga masyarakat atas aspirasi yang mereka kemukakan dengan kondisi riil yang dihadapi oleh pemerintah ketika harus berkoordinasi dengan lembaga legislatif. Dalam kegiatan Government Social Responsibility, terdapat pola integrasi antara pejabat dengan rakyat untuk memecah kebekuan komunikasi yang selama ini terjadi, antara birokrasi dengan masyarakat pada umumnya. Kecurigaan rakyat dan elitisme para birokrat dapat dikikis melalui proses pendekatan yang lebih humanis, di mana melalui Government Social Responsibility dapat membangun wacana egaliter di antara mereka yang terlibat di dalamnya.

Meski demikian, Government Social Responsibility yang berlaku pada dasarnya memiliki gambaran kedua perspektif sebagaimana disinggung sebelumnya, yaitu keterkaitan antara program dan kebijakan dengan kepentingan masyarakat dan pemerintah, secara simbiosis mutualisme. Permasalahan yang mengemuka serta temuan hasil penelitian di lapangan, titik berat dari penelitian ini adalah upaya mencermati atau menelaah secara mendalam dan komprehensif terhadap berbagai aspek, seperti; 1) Mengidentifikasi program Government Social Responsibility dalam mengembangkan pola komunikasi antara pemerintah daerah dengan masyarakat miskin (tahun pertama); 2) Mengidentifikasi fungsi Government Social Responsibility dalam menentukan kebijakan yang aspiratif, partisipatif, dan sederhana; 3) Menguji peran dan fungsi Government Social Responsibility dalam membangun keberdayaan masyarakat, serta pengaruhnya terhadap upaya penanganan kemiskinan sosial; dan 4) Merancang atau mengembangkan model Government Social Responsibility dalam penanganan kemiskinan sosial secara tepat. 
Penelitian ini memuat tujuan khusus yang dapat dikemukakan, seperti; a) Menambah perbendaharaan dan memperkuat khasanah keilmuan di bidang Ilmu Pengetahuan Sosial (IPS), utamanya bagi pengembangan teori-teori sosial politik; b) Diperoleh hipotesa baru tentang pengaruh Government Social Reponsibility terhadap pemberdayaan masyarakat dan penanganan kemiskinan sosial; dan c) Merancang atau mengembangkan model Government Social Responsibility secara terpadu dalam upaya penanganan kemiskinan sosial.

\section{Metode Penelitian}

Lokasi penelitian di Provinsi Jawa Timur yang diwakili tiga daerah kabupaten dan kota yang masingmasing daerah mencerminkan wilayah administratif masyarakat Jawa Timur. Adapun dua daerah kabupaten yang dimaksud yaitu masyarakat Kabupaten Madiun dan masyarakat Kabupaten Magetan, sedangkan satu daerah kota adalah masyarakat Kota Madiun.

Pengambilan sampel dilakukan melalui cara purposive sampling. Dalam persoalan cara purposive sampling tersebut, Arikunto (1998) menyatakan bahwa “ ... sampel bertujuan dilakukan dengan cara mengambil subyek bukan didasarkan atas strata, random, atau daerah tujuan tertentu”. Teknik pengambilan sampel menggunakan teknik multi stage sampling, dan subyek penelitiannya adalah pejabat pemerintah dan masyarakat di Provinsi Jawa Timur yang diwakili tiga daerah kabupaten dan kota terpilih, yaitu; Kabupaten Madiun, Kabupaten Magetan, dan Kota Madiun yang masing-masing mewakili wilayah administratif Provinsi Jawa Timur. Selanjutnya diambil sebagian selaku sampel sekaligus sebagai responden penelitian secara "purposive sampling".

Teknik pengumpulan data yang digunakan dalam penelitian ini adalah interview (wawancara), observation (pengamatan), dan document (dokumentasi). Untuk menguji keabsahan data dengan menggunakan triangulasi sumber data, dimana pemeriksaan keabsahan data dapat dilakukan melalui cara seperti berikut; a. Membandingkan data hasil kuesioner dengan data observasi di lapangan penelitian; b. Membandingkan data hasil pengamatan dengan data hasil wawancara dari beberapa sumber data; dan c. Membandingkan hasil wawancara dengan isi suatu dokumen yang berkaitan.

Metode analisis data menggunakan model interaktif. Menurut Matthew B. Miles dan Michael Huberman dalam Moleong (2000), dalam melakukan proses analisis komponen utama yang perlu diperhatikan setelah pengumpulan data adalah: a. Reduksi data, yaitu proses pemilihan, penyederhanaan, pengabstrakan dan transformasi data kasar dari catatan-catatan tertulis di lapangan hingga laporan akhir lengkap tersusun; b. Penyajian data, yaitu sekumpulan informasi yang tersusun agar dapat memberi kemungkinan dapat menarik simpulan. Dalam penyajian data ini dilakukan setelah melakukan reduksi data yang akan dipergunakan sebagai bahan laporan; dan c. Menarik simpulan atau verifikasi, yaitu berupa intisari dari penyajian data yang merupakan hasil dari analisis yang dilakukan dalam penelitian.

\section{Hasil dan Pembahasan}

Penanganan kemiskinan sosial merupakan tugas pokok dan fungsi pemerintah, tetapi secara riil hal tersebut secara sepenuhnya merupakan tanggung jawab bersama dari seluruh elemen masyarakat (lapisan dan tingkatan), dalam hal mana, permasalahan tersebut berlangsung dari waktu ke waktu. Mengenai tujuan khusus penelitian, adalah menemukan model penanganan kemiskinan sosial, melalui Government Social Responsibility. Untuk tahun pertama; a) meneguhkan pola komunikasi antara pemerintah dengan warga masyarakat miskin; dan b) mengidentifikasi fungsi Government Social Responsibility dalam upaya pemberdayaan masyarakat miskin.

Identifikasi karakteristik Government Social Responsibility dalam mengembangkan pola komunikasi antara pemerintah daerah dengan masyarakat miskin (tahun pertama). Temuan-temuan data di dalam proses penelitian, diperlukan perunutan lebih lanjut bagi terbukanya peluang kaji analisa terhadap masalah pengembangan pola komunikasi yang telah berlangsung selama ini. Tujuan yang ingin 
dicapai tentunya lebih mengedepankan prospek penanganan kemiskinan sosial terkait perspektif tansformasional kepentingan rakyat berdasarkan program-program Government Social Responsibility, dengan keterlibatan aspirasi dan partisipasi riil dari warga masyarakat miskin, sehingga permasalahan sebenarnya di lapangan secara lambat-laun dapat diuraikan secara rinci.

Sebagai resiko logisnya, masih terdapat beberapa program yang belum tersentuh ataupun tersentuh sebagian yang menjadi target pada tahun anggaran berjalan, ketika urgensi penanganan kemiskinan sosial pada tahun anggaran berikutnya merupakan tindak lanjut yang mencerminkan kesinambungan program-program sebelumnya. Dengan keadaan demikian sifat perencanaan, pelaksanaan, serta evaluasi berdasarkan kepada proses yang melibatkan elemen masyarakat secara aspiratif dan partisipatif, kurang terlihat peran dan sosoknya. Di satu sisi, pemerintah selaku pemegang kepercayaan berkewajiban untuk menentukan kebijakan-kebijakan dalam menjalankan tugas pokok dan fungsinya, maka setiap program yang terkait dengan kepentingan masyarakat menjadi kewenangan atau otoritasnya berdasarkan kepada ketentuan perundang-undangan dan hukum yang berlaku. Di sisi lain, masyarakat pada umumnya sebagai sasaran kebijakan, mau tidak mau harus dapat dilaksanakan tanpa adanya peluang dan kewenangan dalam menyuarakan aspirasinya.

Menanggapi keadaan tersebut, pemerintah berinisiatif melakukan sosialisasi kebijakan-kebijakan terkait, kepada warga masyarakat baik secara langsung melalui kunjungan ke wilayah-wilayah sasaran maupun secara tidak langsung melalui stakeholder dan kepala-kepala wilayah serta lembaga-lembaga sosial-kemasyarakatan. Persoalan demikian, mengundang beberapa kritik dan pembanding bahwa topdown planning terkait dengan program-program penanganan kemiskinan sosial merupakan issue yang bersifat umum, sehingga timbul adanya; a. anggapan-anggapan yang kurang menguntungkan, baik dari sisi pemerintah daerah maupun sisi masyarakat dimana keseimbangan hak dan kewajiban dalam masalah penanganan kemiskinan sosial pada dasarnya merupakan tanggung jawab bersama antara pemerintah dengan masyarakat; dan b. Pola komunikasi yang dikembangkan melalui sosialisasi kebijakan-kebijakan pemerintah kepada masyarakat terkait penanganan kemiskinan sosial, baik secara langsung maupun secara tidak langsung, kurang terapresiasi oleh masyarakat miskin secara seutuhnya.

Program penanganan kemiskinan sosial sebagai pertanggungjawaban sosial pemerintah melalui kegiatan-kegiatan government social responsibility yang berkesinambungan, merupakan salah satu bentuk program kegiatan dengan tujuan-tujuan luhur. Keadaan tersebut, secara riil di lapangan terdapat beberapa peluang terjadinya kendala-kendala yang cenderung beresiko di kemudian hari, yakni wilayah-wilayah kantong kemiskinan yang belum tersentuh oleh kegiatan government social responsibility sebagai kegiatan yang bersifat topdwon planning seperti selama ini berlangsung (pemerintah daerah sebagai eksekutor, dari program-perencanaan-pelaksanaan-evaluasi). Mengingat bahwa secara politis, periodisasi masa jabatan kepala daerah dalam kurun waktu 5 (lima) tahunan dengan tugas pokok dan fungsi pemerintahan yang harus dijalankan, dihadapkan kepada kepentingan masyarakat yang kompleks serta beragam, sudah barang tentu, waktu dan kesempatan yang dimiliki oleh pemerintah daerah, diakui atau tidak diakui, adalah sangat terbatas.

Mengidentifikasi fungsi Government Social Responsibility dalam menentukan kebijakan yang aspiratif-partisipatif (tahun pertama). Upaya-upaya pemberdayaan masyarakat miskin sebagai issue yang selama ini selalu menjadi perbincangan, baik oleh para penentu kebijakan maupun pada umumnya warga masyarakat di berbagai kesempatan. Terutama terkait fungsi dan arah dari pembangunan bagi keberdayaan warga masyarakat miskin, melalui kegiatan-kegiatan Government Social Responsibility yang dari waktu ke waktu diselenggarakan oleh pemerintah daerah berdasarkan program-program pembangunan terkait. Keadaan kemiskinan sosial di lingkungan di mana warga tinggal, merupakan tantangan yang mendesak untuk menemukan jawaban secara berkesinambungan, mengingat besaran warga yang mengalami keadaan tersebut cenderung semakin bertambah. Upaya pengentasan kemiskinan sosial melalui penguatan dan pemberdayaan masyarakat, tidak terlepas dari keseluruhan proses serta prosedur yang selama ini oleh sebagian warga masyarakat dirasakan sebagai "belum menjawab dan menyentuh" persoalan yang menjadi pokok perhatian, yaitu kemiskinan sosial dimaksud. 
Untuk itu, sangat perlu dilakukan pendataan yang benar-benar akurat, dalam hal mana, keberadaan mereka tersebar di seluruh wilayah sehingga diperlukan kecermatan serta kehati-hatian. Sangat perlu dilakukan pengkajian lebih mendasar terhadap data akurat dan informasi aktual sebagaimana transformasi kepentingan rakyat yang telah disinggung. Sebagai resiko logisnya, adalah wajar apabila kemiskinan sosial mengalami pertumbuhan dari tahun ke tahun, di mana setiap warga masyarakat baik secara individu maupun secara sosial memiliki hak dan kewajiban yang kurang-lebih sama, yaitu bertanggung jawab di dalam dan terhadap kehidupan.

Keterbatasan lapangan kerja yang berlaku di dalam lingkup daerah, tentunya berpengaruh terhadap terbatasnya gerak dan langkah warga masyarakat untuk melakukan kegaiatan-kegiatan yang bersifat ekonomis. Perolehan pendapatan di daerah sendiri, merupakan sebuah kesempatan serta kemudahan yang berharga bagi warga untuk memenuhi berbagai kebutuhan di dalam kehidupannya melalui daerah sendiri dan menjadi potensi sumber daya masyarakat yang dapat memperkuat kebijaksanaan pembangunan secara lebih maksimal. Pemberdayaan masyarakat merupakan bagian terpenting di dalam upaya pengentasan kemiskinan sosial yang dihadapi oleh sebagian warga di mana mereka tinggal, dan pendekatan-pendekatan terkait persoalan tersebut harus dijangkau berdasarkan perencanaan yang mendasar. Artinya, tindakan bersama (pemerintah-masyarakat) yang mengarah kepada upaya pengentasan kemiskinan sosial secara teratur dan berkesinambungan, merupakan langkah-langkah Government Social Responsibility yang dilakukan melalui proses pemberdayaan masyarakat (tingkat pendapatan, tingkat pendidikan, tingkat kesehatan, stimuli kepada warga yang malas).

Government Social Responsibility melalui kunjungan kerja sebagai kegiatan, selain bertemu secara langsung dengan warga masyarakat di wilayah-wilayah desa/kelurahan, sangat utama adalah mendata berbagai persoalan yang dihadapi oleh warga masyarakat terkait dengan permasalahan pemberdayaan masyarakat bagi penanganan kemiskinan sosial. Kegiatan pemerintah kabupaten/kota tidak terlepas dari visi, misi, dan tujuan yang berhubungan secara langsung ataupun secara tidak langsung dengan persoalan kemiskinan sosial, melalui transformasi kepentingan rakyat. Pemikiran seperti itu, tidak menutup kemungkinan adanya keterangan-keterangan sebagai umpan balik (feedback) dari situasi (keadaan), kondisi (kemampuan), dan toleransi (penerimaan positif dan negatif). Penjelasan yang saling mendukung di dalam menyikapi persoalan-persoalan kompleks yang berkembang serta dihadapi oleh masyarakat, dapat menjadi informasi bagi pemerintah daerah di dalam ranah pemberdayaan masyarakat melalui transformasional kepentingan rakyat, seperti program kunjungan kerja atau dikenal sebagai silaturahim di Kota Madiun, Bhakti Sosial Terpadu di Kabupaten Madiun, dan Saba Desa untuk Kabupaten Magetan selama ini, guna menemukan dan menghimpun data serta informasi sebanyak dan seutuh mungkin. Artinya, jajaran pemerintah memiliki tugas pokok dan fungsi bagi terselenggaranya pembangunan di seluruh wilayah serta bidang sasaran, salah satunya adalah pembangunan sosial yang tidak dapat dilepaskan dari penanganan kemiskinan sosial secara terus-menerus dan berkelanjutan.

Transformasional kepentingan rakyat oleh jajaran pemerintah sebagai tindakan menuju pemberdayaan masyarakat, tidak melepaskan kewajiban dan hak warga masyarakat untuk berpartisipasi guna memperkuat kepedulian bersama bagi upaya pengentasan dan penanganan kemiskinan sosial yang ada dan dihadapi bersama. Demikian halnya dengan pelaksanaan pembinaan sumber daya yang tersedia, bersama antara warga masyarakat dan para stakeholder dengan pemerintah daerah beserta jajaran terkait program-program pemberdayaan masyarakat. Mengenai sumber daya yang tersedia, antara lain sumber daya manusia (SDM) sumber daya masyarakat (SDMs), sumber daya alam (SDA), sumber daya keuangan (SDKeu), dan sumber daya teknologi (SDTh) merupakan potensi-potensi daerah yang dapat dikelola, dikembangkan, dan dimanfaatkan secara sepenuhnya, tepat guna dan tepat sasaran. Berdasarkan hasil sementara penelitian, diketahui bahwa warga masyarakat belum sepenuhnya memahami sumber daya sebagai potensi yang dimiliki daerah di mana warga tinggal, maka pilihan jawaban yang ditentukan oleh para responden penelitian adalah berkatagori sedang. Artinya, pemahaman warga masyarakat terhadap potensi yang tersedia di daerah masih terus dapat ditingkatkan, sehingga pemahaman terhadap pemanfaatannya dapat diselenggarakan secara maksimal, hingga upaya pemberdayaan masyarakat lambat-laun juga terwujudkan. 
Penanganan kemiskinan sosial merupakan tugas pokok dan fungsi pemerintah, tetapi secara riil hal tersebut secara sepenuhnya merupakan tanggung jawab bersama dari seluruh elemen masyarakat (lapisan dan tingkatan), karena permasalahan tersebut berlangsung dari waktu ke waktu. Mengenai tujuan khusus penelitian, adalah menemukan dan mengembangkan model penanganan kemiskinan sosial, melalui Government Social Responsibility. Untuk tahun kedua pelaksanaan penelitian mencakup; a) menguji esensi Government Social Responsibility dalam pemberdayaan masyarakat dan penanganan kemiskinan sosial; dan b) mengembangkan atau merancang model Government Social Responsibility dalam penanganan kemiskinan sosial.

Jalinan hubungan yang harmonis memberikan sikap saling percaya antara pihak-pihak yang terlibat di dalamnya (pemerintah bersama masyarakat), ibarat hidup dan kehidupan manusia sendiri, yaitu menyatunya antara tubuh dengan roh dan jiwa yang saling mempengaruhi serta saling mengisi. Dengan demikian, pemerintah daerah tidak dapat tinggal diam terhadap keadaan dan kenyataan yang terjadi di wilayahnya, dalam hal mana, merupakan prinsip yang harus selalu diperhatikan serta dikelola untuk prakarsa-prakarsa ke arah masa depan yang lebih maju sehingga mampu di dalam bertindak. Dengan demikian, pemerintah daerah harus selalu berupaya untuk dapat menjalin kebersamaan secara internal maupun secara eksternal di dalam pencapaian kesejahteraan sosial bagi masyarakat secara umum dan saling menguntungkan, di dalam kerangka upaya penanggulangan kemiskinan sosial yang menyebabkan terjadinya ketertinggalan.

Menguji esensi Government Social Responsibility dalam pemberdayaan masyarakat dan penanganan kemiskinan sosial. Dapat diketahui bahwa mengenai perkembangan dan perubahan terkait upayaupaya penanggulangan kemiskinan sosial oleh pemerintah daerah kabupaten dan kota belum menampakkan hasil sebagaimana target-target yang telah ditetapkan sebelumnya. Bahwa pertanggungjawaban sosial pemerintah sebagaimana berlangsung dari tahun ke tahun dan berkesinambungan, merupakan wujud bagi terselenggaranya kepedulian pemerintah kepada masyarakat, di mana, dukungan masyarakat kepada pemerintah belum menampakkan sosoknya secara utuh di dalam keterbukaan komunikasi sosial. Akibatnya adalah terjadi serta berlangsung di dalam masyarakat, baik secara individu maupun secara sosial langkah-langkah penyelenggaraan programprogram pemerintah yang ditujukan kepada kepentingan sosial bersama belum dapat terlaksana secara "tepat sasaran dan tepat manfaat". Dengan demikian, harapan bahwa upaya pemberdayaan masyarakat bagi penanganan kemiskinan sosial berdasarkan langkah-langkah transformasional yang selama ini dilakukan, kurang dan belum dapat meningkatkan pengetahuan dan pemahaman masyarakat baik secara individu maupun secara sosial, dalam rangka penanggulangan kemiskinan sosial, terkendala sehingga belum dapat terlaksana secara signifikan.

Peristiwa seperti itu, lepas kaitannya dengan prinsip jalinan hubungan yang harmonis memberikan sikap saling percaya antara pihak-pihak yang terlibat di dalamnya (pemerintah bersama masyarakat), di dalam berbagai lini kehidupan. Untuk itu, diperlukan adanya peluang-peluang bagi akses informasi program-program pemberdayaan masyarakat bagi penanganan kemiskinan sosial yang lebih memadai, sehingga ide dan gagasan yang berasal dari masyarakat (bottom-up planning) merupakan bagian dari program-program daerah yang memiliki nilai seimbang dengan program-program yang ditetapkan oleh pemerintah daerah. Karakteristik komunikasi seperti itu, merupakan kegiatan yang sering dikenal dengan sebutan pemerintah sebagai eksekutor, dimana program pemberdayaan masyarakat bagi penanganan kemiskinan sosial menjadi tanggung jawab pemerintah melalui sosialisasi secara langsung. Sedangkan masyarakat secara pasif merupakan sasaran atau obyek yang menjadi bagian dari tugas pokok dan fungsi pemerintah daerah bagi penyelesaian kemiskinan sosial.

Dengan turun langsung ke wilayah warga masyarakat yang kurang beruntung (miskin), pemerintah daerah beserta jajaran dapat memahami kondisi riil dari kehidupan warga masyarakat kurang beruntung, pendekatan yang lebih humanis dapat membuahkan kebersamaan, dan dapat memecah kebekuan komunikasi yang terjadi antara pemerintah dengan warga masyarakat. Aksi "jemput bola" yang dilakukan oleh pemerintah daerah beserta jajaran dengan turun langsung di dalam persoalan yang dihadapi masyarakat, dapat diharapkan secara lambat-laun menyerap berkembangnya aspirasi dan berupaya semaksimal mungkin merespon dan secepatnya merealisasi aspirasi tersebut dalam 
bentuk rumusan kebijakan yang aspiratif dan sederhana. Berkembangnya mekanisme penyelesaian persoalan sosial itu, di satu sisi, dapat terbangun transparansi dalam pengambilan kebijakan sehingga dapat mengurangi kecurigaan masyarakat terhadap elitisme birokrasi, dan di sisi lain, dapat terbangun suasana egaliter di antara pihak-pihak yang terlibat di dalamnya.

Selanjutnya, pemberdayaan masyarakat merupakan kegiatan yang berorientasi pada pengembangan, memandirikan, serta memberdayakan masyarakat bawah agar memiliki kekuatan tawar-menawar (bargainning power) di segala aspek kehidupan. Pemberdayaan masyarakat sebagai sebuah proses yang tidak mungkin dilakukan secara setengah-setengah (partial), proses ke arah itu memerlukan strategi yang bersifat menyeluruh, terus-menerus, berkelanjutan, dan seutuhnya. Pemberdayaan masyarakat tidak bersifat kekhususan, seperti individu atau kelompok masyarakat lapisan bawah (grass-roots), masyarakat pinggiran (local areas), ataupun pedesaan (rural communities) yang menjadi sasaran kebijakan pembangunan sosial. Pengartian demikian, sering dikaitkan dengan kekuasaan yang diartikan sebagai kemampuan untuk mempengaruhi agar yang dipengaruhi bersedia melakukan sesuatu perbuatan sesuai dengan keinginan yang mempengaruhi, terlepas dari keinginan yang dipengaruhi. Kekuasaan selalu hadir di dalam setiap hubungan-hubungan sosial antar manusia, baik sebagai individu maupun sebagai warga masyarakat, pemberdayaan merupakan sebuah proses perubahan dari suatu keadaan yang dianggap kurang sebelumnya, kepada keadaan yang dirasa lebih daripada sebelumnya. Menurut pernyataan tersebut, maka antara kekuasaan dengan berdaya memiliki persamaan dalam arti luas dan merupakan peluang strategis serta diperlukan pensikapan berdasarkan adaptasi dan adopsi terhadap keberadaan lingkungan sosial-kemasyarakatan.

Mengembangkan atau merancang model Government Social Responsibility dalam penanganan kemiskinan sosial. Pada prinsipnya, Government Social Responsibility telah mengurangi kesenjangan yang terjadi di dalam komunikasi antara pejabat dengan rakyat secara aspiratif, akurat, dan sederhana sehingga alur kebersamaan mulai tercipta melalui mekanisme semacam ini. Dengan menjelaskan kemampuan dan kondisi senyatanya yang dimiliki pemerintah, ternyata menimbulkan rasa simpati dari masyarakat untuk ikut-serta di dalam proses pembangunan, tanpa menggantungkan pada uluran tangan pemerintah sepenuhnya. Keterangan tersebut, menunjukkan bahwa pemerintah tidak dapat menyelesaikan kegiatan pembangunan melalui kemampuan sendiri tanpa adanya keterlibatan secara aktif dari warga masyarakat.

Melalui penyerapan aspirasi dalam suasana yang humanis, bersahabat, dan fleksibel antara para penentu kebijakan dengan masyarakat, merupakan wujud demokrasi yang amat luhur yakni aspirasi dengan kebijakan, baik aspirasi secara tidak tertulis atau lisan maupun tertulis. Berbagai aspirasi masyarakat yang menyangkut permasalahan serius, dapat diakomodasi secara langsung oleh dinas terkait yang siap memback-up kebijakan pemerintah daerah. Mekanisme yang demikian, dapat memotong mata-rantai alur pengambilan kebijakan yang sangat panjang dan memerlukan waktu lama. Dengan demikian, Government Social Responsibility dapat menjadi model pengambilan kebijakan yang akurat, aspiratif, dan sederhana. Berdasarkan pemikiran dan penjelasan sebagaimana mengemuka sebelumnya, dapat dipahami bahwa Government Social Responsibility sebagai sebuah terobosan baru oleh pemerintah daerah, merupakan upaya memecah kebekuan komunikasi antara pemerintah dengan masyarakat, sehingga tercipta ruang aspirasi dan kepentingan masyarakat kepada pemerintah menjadi lebih terbuka. Keadaan ini diharapkan dapat ditemui di lapangan, bahwa sebelumnya secara riil pola komunikasi antara pemerintah dengan masyarakat berlangsung lebih bersifat instruktif, apatis, semata-mata sebagai obyek, hanya menerima dan melaksanakan program yang berasal dari pemerintah.

Keterlibatan masyarakat di dalam proses keputusan-keputusan (kebijakan) pembangunan dapat diharapkan adanya keswadayaan masyarakat, dalam hal mana, secara psikologis memberikan perspektif terhadap warga yang kurang beruntung secara positif, warga masyarakat yang kurang beruntung tidak lagi dipandang sebagai serba kekurangan dan sebagai obyek penerima pelayanan belaka, misalnya kurang makan, kurang pendapatan, kurang sehat, kurang dinamis, dan sebagainya. Bahwa di dalam masyarakat didapati sebagian dari warga miskin sehingga kenyataan tersebut mengundang perhatian dari berbagai elemen dan unsur masyarakat (lapisan dan tingkatan) guna 
mengupayakan penanganannya. Tidak luput dari perhatian itu, pemerintahan daerah beserta jajaran secara terus-menerus dan berkelanjutan selalu berkoordinasi dengan berbagai pihak, melalui berbagai kegiatan yang sering dikenal dengan transformasi kepentingan rakyat untuk melihat secara dekat terkait dengan situasi (keadaan), kondisi (kemampuan), dan toleransi (penerimaan-positif dan negatif) bagi warga masyarakat pada umumnya, dan warga masyarakat kurang beruntung pada khususnya.

Persoalan kemiskinan bagaikan benang kusut yang tidak mudah untuk diurai, kebijakan yang berorientasi kepada bantuan sosial pelaksanaannya mengalami kendala, dimana sifat bantuan belum mengarah kepada pemberdayaan masyarakat, dan tidak kurang bahwa bantuan sosial tersebut menimbulkan efek ketergantungan. Keterbatasan ruang dan kesempatan bagi keterlibatan warga masyarakat yang kurang beruntung secara aktif di dalam proses kebijakan, merupakan faktor yang menghambat dan menyebabkan terjadinya kurang sinergi antara program pemerintah dengan kebutuhan masyarakat. Memperhatikan upaya-upaya yang dilakukan oleh pemerintah daerah bersama masyarakat di dalam mensikapi keadaan seperti itu, tidak sedikit ajakan kepada warga yang belum beruntung untuk berani keluar dari lilitan keadaan yang dihadapi agar memiliki kehidupan yang lebih baik. Pada dasarnya, upaya penanganan kemiskinan sosial di dalam menentukan kebijakan pembangunan, sangat diperlukan peran-serta warga masyarakat yang kurang beruntung bagi penyerapan aspirasi mereka.

Kegiatan sosial yang dilaksanakan oleh pemerintah daerah, dapat menciptakan keswadayaan masyarakat melalui program stimulan yang disampaikan secara langsung kepada kelompok-kelompok masyarakat (pokmas). Dengan penjelasan tentang kemampuan dan keadaan senyatanya yang dimiliki pemerintah membuat masyarakat simpati, dapat memahami, dan tergerak untuk ter-(di)-libatkan di dalam proses pembangunan tanpa menggantungkan sepenuhnya pada uluran tangan pemerintah. Ruang transparansi dan akuntabilitas, dibuka selebar mungkin untuk mengurangi rasa curiga masyarakat atas aspirasi yang mereka ungkapkan terhadap kondisi riil yang dihadapi pemerintah daerah, dalam koordinasinya dengan pihak legislatif.

\section{Simpulan}

Keterkaitan antara topdown planning dengan keterbukaan partisipasi masyarakat yang berlangsung berdasarkan program-program penanganan kemiskinan sosial, berpengaruh secara signifikan terhadap pola rekrutmen stakeholder di dalam trasformasional kepentingan rakyat dan berakibat pada realisasi terhadap aspirasi dan partisipasi masyarakat cenderung kurang tersentuh. Dengan demikian perencanaan, pelaksanaan, dan evaluasi terhadap penyelenggaraan Government Social Responsibility di wilayah atau lapangan penelitian belum memenuhi kriteria yang telah ditetapkan pada tujuan program-program penanganan kemiskinan sosial dimaksud. Sebagai resiko logisnya, masih terdapat beberapa program yang belum tersentuh ataupun tersentuh sebagian yang menjadi target pada tahun anggaran berjalan, dimana urgensi penanganan kemiskinan sosial pada tahun anggaran berikutnya merupakan tindak lanjut yang mencerminkan kesinambungan program-program sebelumnya. Dengan keadaan seperti itu sifat perencanaan, pelaksanaan, serta evaluasi berdasarkan proses yang melibatkan elemen masyarakat secara aspiratif dan partisipatif, kurang terlihat peran dan sosoknya.

Dalam menanggapi keadaan tersebut, pemerintah berinisiatif melakukan sosialisasi kebijakankebijakan terkait kepada warga masyarakat, baik secara langsung melalui kunjungan ke wilayahwilayah sasaran maupun secara tidak langsung melalui stakeholder serta lembaga-lembaga sosialkemasyarakatan. Sudah barang tentu hal tersebut dapat diberikan beberapa kritik bahwa topdown planning terkait dengan program-program penanganan kemiskinan sosial merupakan issue yang bersifat umum, sehingga timbul adanya; anggapan-anggapan yang kurang menguntungkan, baik dari sisi pemerintah daerah maupun sisi masyarakat dimana keseimbangan hak dan kewajiban di dalam masalah penanganan kemiskinan sosial pada dasarnya merupakan tanggung jawab bersama antara pemerintah dengan masyarakat. Ikatan antara pemerintah daerah dengan lembaga perwakilan rakyat daerah di dalam menentukan kebijakan-kebijakan terkait penanganan kemiskinan sosial, sangat menyita waktu dan kesempatan di dalam upaya merealisasikan program-program dimaksud dan ditujukan kepada masyarakat. Proses penentuan program-program penanganan kemiskinan sosial, 
kurang memperlihatkan bahwa keterlibatan elemen masyarakat masih sangat kecil di dalam perencanaan, pelaksanaan, dan evaluasi secara aspiratif dan partisipatif. Pola komunikasi yang dikembangkan melalui sosialisasi kebijakan-kebijakan pemerintah kepada masyarakat terkait penanganan kemiskinan sosial, baik secara langsung maupun secara tidak langsung, kurang terapresiasi oleh masyarakat miskin secara seutuhnya.

\section{Daftar Pustaka}

Baru BM, Sudjatmoko FX \& Iswati R (2002) Partisipasi Masyarakat dan Pengaruhnya terhadap Kemiskinan Masyarakat. Madiun: Kajian TimFK3 Fisip-Unmer.

Baru BM, Sudjatmoko FX \& Iswati R (2008) Studi Deskriptif: Pelibatan Masyarakat dalam Mekanisme Penyusunan Program Pembangunan. Madiun: Kajian Tim FK3 Fisip-Unmer.

Moleong L (1994)_Metode_Penelitian_Kualitatif. Bandung: Pustaka Remaja Rosdakarya.

Sudjatmoko FX \& Baru BM (2009) Identifikasi Faktor Budaya Jawa dan peran Gender Wanita, implementasinya dalam pembangunan, di kabupaten Madiun Jawa Timur. Hasil Penelitian, Jakarta.

Arikunto S (1992) Prosedur Penelitian Suatu Pendekatan Praktek. Jakarta: Rineka Cipta. 